\title{
The New Rules on Bank Remuneration Policies Reception by the Three Major Italian Banking Groups
}

\author{
Angela Gaizo, PhD Candidate \\ Gianluca Risaliti, Prof. \\ Department of Business and Economics Studies, \\ University of Napoli Parthenope, Italy \\ Marco Rotili, PhD Candidate ${ }^{1}$ \\ Department of Business Studies, University of Roma 3, Italy
}

Doi: 10.19044/esj.2018.v14n7p386 URL:http://dx.doi.org/10.19044/esj.2018.v14n7p386

\begin{abstract}
:
The compensation and incentive systems of executive directors have been the subject of particular attention by scholars and regulators for their significant implications on an economic and social level. Especially in the aftermath of the Global Financial Crisis of 2007, compensation practices based on short-term profits were accused of having significantly increased the risk-taking that threatened the global financial system. In order to avoid this repercussion, the European Community and Italian regulators issued instruments for encouraging banks to implement remuneration systems complying more with their operational and dimensional characteristics. The last of these rules in the Italian legal framework was the VII Update of "Circolare $N^{\circ} 285$ of $17^{\text {th }}$ December 2013" which examines the new rules about the remuneration of bankers and executives in the Italian financial sector, and the impact of these rules on the three Italian larger significant banks. Results show that the three Italian banks have not been strongly impacted by these rules. Since 2013, in fact, the remuneration system of the three banking groups examined were characterized by a proper balancing between the fixed and the variable component of remuneration, as well as by a binding (ex-ante and ex-post) adjusting system. Above all, the new rules have affected the number of the "material risk-takers", which increased in 2015.
\end{abstract}

Keywords: remuneration; CRD IV (EU Capital Requirements Directive); Single Supervisory Mechanism (SSM); golden parachutes; Circolare $\mathrm{N}^{\circ}$

\footnotetext{
${ }^{1}$ University of Rome 3 and Bank of Italy. The opinions expressed and conclusions drawn are those of the author and do not necessarily reflect neither the views of Bank of Italy, nor those of the other mentioned Institutions.
} 
285/2013, Bank of Italy.

\section{Introduction and research objectives}

Since the global financial crisis of 2007, the compensation and incentive systems policies and practices in banks and banking groups have been subject to special attention, not only by international bodies and regulators but also by scholars and by public opinion, due to the considerable implications of these matters at economic and social level (De Poli, 2013).

In fact the crisis brought to light the deficiencies existing in Corporate Governance systems and in a particular way in the policies and forms of remunerating management, which often turned out to be unsuitable and a determining factor in excessive assumption of risks on the part of intermediaries (Furlan, Cremascoli, Paglionico, 2011; Vitali, Miramondi, 2014).

The unsuitability of remuneration systems in the financial sector derives chiefly from the structure of such systems, from the adoption of "inappropriate" incentivizing mechanisms and from the amount, in absolute value, of the remunerations paid (Nigro, 2014).

For this reason, both US and EU regulators have been concerned to introduce restrictions on the amounts and timing of cash rewards granted to bank management and employees, on the assumption that these may be based in on "illusionary" profit (Livne, Markarian and Milne, 2011).

In particular, in 2014, on the proposal of the European Banking Authority (EBA), the European Union issued the new Regulatory Technical Standards (RTS). The RTS refers to suitable qualitative and quantitative criteria for identifying the category of personnel whose professional activities have a substantial impact on the risk profile of the body (Material Risk Takers). This boundary line takes on particular importance as it identifies the persons primarily subject to the abovementioned restrictions and deferral clauses.

Subsequently, on $18^{\text {th }}$ November 2014, the Bank of Italy, in application of the Directive 2013/36/EU (so-called CRD IV), issued the VII Updating of Circolare $N^{\circ} 285$ of $17^{\text {th }}$ December 2013, indexed as "Politiche e prassi di remunerazione e incentivazione" (hereinafter for brevity, "Provision").

This Provision clarifies certain aspects of the previous regulations and renders them coherent with the new rules on the subject of company governance (a theme closely linked to the discipline of compensations) and with the recent coming into force of the Single Supervisory Mechanism, SSM ${ }^{2}$

\footnotetext{
${ }^{2}$ The Single Supervisory Mechanism (or SSM) was instituted in accordance with EU Regulation $\mathrm{N}^{\circ} 1024 / 2013$ which concentrates under the ECB specific duties regarding prudential supervision of credit institutions. The constitution of the SSM is of fundamental importance to the constitution of the Banking Union. It ensures "that the Union's policy on prudential supervision of credit institutions is implemented coherently and efficiently, that the single corpus of regulations on financial services is applied in the same way to credit institutions in
} 
(Bentivegna, 2016). Moreover, it inserts important innovations with regard to the former approach to the matter. In fact, the Provision intervenes in fields formerly left to the private autonomy of the subjects supervised. By imposing significant prudential overseeing, it mitigates the need for a better, long term and risk sensitive alignment, between remunerations and company performances.

In a special way the new rules, though sharing the substantial baselines of the previous ones ${ }^{3}$, intervene in certain aspects such as: (i) the role of the meeting, which under several profiles is extended and valorised; (ii) the structure of remuneration, with the setting of a cap to the incidence of the variable proportion of remuneration with regard to the fixed one, and the clarification of several profiles concerning the composition of the variable component of remuneration; (iii) the mechanisms of ex-post corrections of variable compensations ("malus" and "clawback") rendered more incisive and anchored to conditions also linked to the "quality" of the beneficiary's conduct; (iv) the proportion of remuneration regarding the final moment of the work relationship, or the moment successive to it (so-called "golden parachutes" and discretional pension benefits) which must be connected with company performances, subject to the period of deferral, and to the abovementioned malus and clawback clauses.

Setting itself in the context of the studies of Agency Theory, the purpose of this work is to carry out a first analysis of the regulations and their repercussions on the choices made by some large Italian banking groups on the subject of remuneration.

Given the foregoing, the paper originates from two fundamental research objectives:

O1) to analyse the regulatory innovations brought by recent provisions on the subject of Remuneration;

O2) to verify how these regulations were received by certain large Italian banks, with special emphasis on research into any intervening alterations in their remuneration systems (the sample is represented by the three main Italian banking groups, classified in function of the total assets of their balance).

As the operating and regulatory environment in which banks compete changes, the incentives provided to the management changes as well (Becher

all the member States involved and that these credit institutions undergo optimal supervision under a qualitative profile, free from considerations extraneous to the prudential viewpoint" (Art. 12 of COUNCIL REGULATION (EU) N. 1024/2013).

${ }^{3}$ It is pointed out among other things that Provision B.I. of 30 $0^{\text {th }}$ March 2011 regarding the policies and practices of remuneration and incentivizing in banks and banking groups largely confirmed, in turn, the principles and criteria contained since 2008 in the provisions issued by the Bank of Italy itself. 
D. A., Campbell II T. L., Frye M. B, 2005) and consequently their remunerations; and as this environment underwent significant modifications immediately after the crisis of 2009 with the adoption of the Commission Recommendation of 30 April $2009^{4}$, the following hypothesis was therefore formulated:

H1) the regulations do not modify, except marginally, the banks' remuneration and incentivizing systems.

This established, it is at once appropriate to underline that the work has certain limitations, yet these may be overcome with subsequent research developments.

The first limitation is connected with the size of the sample employed for the empirical analysis, which is represented by only the three leading Italian banks in terms of total assets in their balance. On the other hand, notwithstanding the thirteenth investigation into the major international banks, carried out by Mediobanca for the year 2016, considers only the two major banks (Intesa San Paolo and Unicredit) as representative of the Italian situation.

The second limitation is to be found in the timespan considered for the empirical analysis (2013 and 2015).

Lastly, the third limitation is linked to the lack, at least in this introductory research phase, of comparisons at European and international level.

\section{Conceptual framework and existing literature}

The vast field of national and international economics literature has always been interested in decisions on the subject of remuneration policies (among others, Murphy, 1985; Sloan, 1993; Hubbard, Palia, 1995; Demsetz, Villalonga, 2001; Duffhues, Kabir, 2008; Shlomo, Wolfgang Eggert, Nguyen, 2013) to the extent that this academic prolusion very soon became the gauge of the "best practices" current from time to time, going on to become the conceptual architecture of the various important regulatory interventions.

The historical conceptual approach to decisions in matters of remuneration policies, which elicited regulatory interventions that were streamlined and rich in references to operational praxis and best practices, stood as a singular and exemplary element of the more encompassing theoretical thread of "agency reports". In any kind of business, in fact, the non-correspondence between the "natural person-shareholder" and the "natural person-manager" (an element typical of the Anglo-Saxon market, less for the central-European market) generates the so-called "conflict between principal (i.e. the shareholder) and agent (i.e. the manager or head of the business)"; there reigns therefore a

4 This Commission Recommendation intended to complement Recommendations 2004/913/EC and 2005/162/EC as regards the regime for the remuneration of directors of listed companies. 
natural relationship of delegation between the one who grants (the shareholder) and the one who manages (with the aim of maximizing profits drawn) the company assets (Berle and Means 1932; Jensen, Meckling, 1976, Holmstrom, 1979). Hence the need to intervene, also through the policies and practices of remuneration, to favour realignment between the interests of those who bring capital and those who manage and positively exploit it (Bebchuk, Fried, 2004; Ferrarini, Ungureanu, 2014).

In fact, by favouring the monitoring of managers' actions, remunerations represent (at least theoretically) an instrument of containment of agency costs, inasmuch as they favour the convergence of the interests of management and those, conflicting, of the owners, towards the same objective of creating sustainable economic value over time (Intonti, 2011). Contrarily, when the incentives system is not suitably linked to performances, not only does one create the premises for a divergence of interests between management and owner. Moreover, the company also runs the risk of losing human resources of high professionalism, since these people will be incentivized to seek other companies that value their skills (Fama, 1980; Lambert, Larker, 1985; Murphy, 1999; Core et al., 1999, 2001; Bebchuk, Fried, 2003).

The extension of profit-sharing to the manager would realign his interests with those of his "principal", however it would remove the distinction of being the bearer of the "ontological risk" of the business; so it is necessary to provide, side by side with the component of the manager's physiological fixed remuneration, also for a proportion of variable remuneration correlated with the results he achieves.

This traditional conflict between shareholders, managers and administrators happens not only in industrial enterprises but also in banks which, like any other kind of business, may be subject to misalignments of incentives among the various players, to weaknesses in internal control systems, incompetence and fraud. Moreover there may emerge specific problems linked to the very nature of banking, such as subjection to a strong political influence (Becht, Bolton, Röell, 2011).

So far a fairly clear logical scheme but, as experienced during the years of the financial crisis, also harbinger of an even graver re-proposition of the conflict of interest inherent to the agency contract. In fact the shareholder is, by definition, the ontological bearer (as long as the share of capital is maintained, even if at the moment of alienation he actualizes expected flows and risks) of the company risk; whereas the manager can get out by cancelling his contract and the administrator can do so by discontinuance of his office. So, an excessive correlation of top staff's remuneration with the business trend of the company could be the harbinger of a management attitude characterized by the carrying out of company operations that bring in great profits (and 
therefore great risks) in the short term, and entail great costs (that is, manifestation of the abovementioned risks) in the longer term. This conceptual element manifested itself during the financial crisis where the phenomenon of "short termism", associated with an increase in operations of securitization (originate-to-distribute model), contributed to conflict of interests between owners and management, as well as between management and the rest of the stakeholders (and in this the remuneration and incentive systems then in place also played a part, though not as sole and preponderant elements) (Laverty, 1996; Dallas, 2011). Within this context lie the regulatory interventions, at various levels, aiming at facing the contrasting needs:

(i) to safeguard the freedom of economic initiative (for example how and how much to pay one's employees and management) with regard to the necessity of a response to distortive phenomena linked to the rules (and practices) in force on the subject of remuneration policies (i.e. excessive bonuses in the past);

(ii) to favour alignment of owner and management interests with regard to the obligation, under penalty of an even more destabilizing re-proposition of the abovementioned conflicts of interest, to arrest phenomena such as the focalization on policies of maximizing profits in the short term (short termism) or the dimensional growth of volumes of proceeds not followed by a growth in productivity (empire building) and the disbursement of exorbitant severance payments (golden parachutes) (Kanniainen, 2000; Choi, 2004; Bolton, Scheinkman, Xiong, 2006; Hope, Thomas, 2008).

\section{Regulatory framework and reference principles}

Prior to beginning a description of the Provision it should be underscored that it has envisaged a transitory system (phase-in) over the early years of implementing the regulation. Moreover, it has envisaged the graduation of application of the rules (proportionality principle) on the basis of characteristics, dimensions, riskiness and operational complexity of each intermediary. In this section we shall instead describe the regulation in its full adoption and in the panorama of the most important intermediaries (i.e. classified as "Significant Institutions" for the purposes of the Single Supervisory Mechanism or $\mathrm{SSM})^{5}$.

\footnotetext{
${ }^{5}$ The theme of proportionality is one of the fundamental elements in the debate on banking vigilance. In brief, we may say that the Provision: (i) disapplies the regulations concerning for example the "deferral" and the "balancing" of variable remuneration between liquid funds and financial instruments (for intermediaries of smaller size, meaning the so-called Less Significant institutions in terms of SSM classification and with less than $€ 3.5$ billion on the assets side of the balance sheet; (ii) applies halved percentages to the above regulations (for the socalled intermediate banks, meaning Less Significant with assets greater than $€ 3.5$ billion).
} 
The first principle that leaps to the eye on an initial reading of the provision is the analytical definition of the duties of the various company organs on the subject of company "remuneration policies".

At Heading IV, Chapter 2, Section II - Role and Responsibilities of the meeting and the company organs, the Provision in fact lays down that the ordinary meeting, as well as establishing the compensations of the organs nominated thereby, also approves:

(i) remuneration and incentivizing policies in favour of members of the organs with functions of strategic supervision, management and control, and of the remaining personnel;

(ii) remuneration plans based on financial instruments (e.g. stock options and stock grants);

(iii) the criteria for determination of compensation to be agreed upon in the case of early conclusion of the mandate or early withdrawal from office, including the limits fixed for this compensation in terms of yearly income of fixed remuneration and maximum amount deriving from their application (golden parachutes).

At present, therefore, while the organ with functions of strategic supervision (the administrative body) is assigned the task of drawing up, submitting (ex-ante) and monitoring (ex-post) the remuneration policies ${ }^{6}$, decisional power in the matter is assigned to the Shareholders' Meeting. This organism, normally outside the assumption of management-body decisions and in line with the sought-after principle of separateness and impartiality of ownership with regard to management, now has a considerably extended and valorised role within the company in comparison with the previous regulations. In fact, its competences have been widened to the point of being able to raise the maximum limit (the cap) of the variable proportion of remuneration fixed by the same regulations.

Under a subjective profile the Provision instead reaffirms the distinction between prescriptions applicable to all personnel and those of greater rigour applicable to more relevant personnel ("material risk takers"), meaning "all members of staff whose professional activities have a material impact on the institution's risk profile" (Regulations 604/2014/EU) ${ }^{7}$. The rule defines the

\footnotetext{
${ }^{6}$ On this matter an important role is played in the regulation by the internal Board "Remuneration Committee". The Committee (i) expresses an opinion on the achievement of performance objectives, (ii) puts the various remuneration plans to the Board; (iii) supervises correct application of the rules and internal policies on the subject.

${ }^{7}$ As regard the criteria employed to assess whether the influence of the professional activities of personnel with risk profile is substantial, Regulations 604/2014 establish that they "should take account of the potential impact of personnel on the body's risk profile on the basis of powers and responsibilities conferred on them, as well as of the risk and performance indicators of the body itself. Internal organization of the body, and the nature, range and complexity of its activities, should be taken into consideration in the assessment. The criteria must fully
} 
parameters with which to identify the category of exponents, according to an assessment referred to the motivated decision of the individual body: the related parameters however are not directly indicated; the Prescriptions make reference to indices, both qualitative (unalterable and linked to the hierarchical position of the person concerned) and quantitative (under certain conditions not binding, and based on the level of remuneration received) dictated by the EBA (Bentivegna, 2016).

Moreover, in accordance with the section III - Structure of Systems of Remuneration and Incentivizing - that establishes that "the entire remuneration is divided between the fixed and variable components", and that the relationship between the two components "must be appropriately balanced, precisely determined and carefully evaluated in relation to the characteristics of the bank and of the different categories of personnel", the innovative element which is perhaps most controversial and disruptive concerns, in agreement with what is expressed in CRD 4, the introduction of a cap to the incidence of the variable remuneration proportion. This cap is expressed in relative terms with regard to fixed remuneration, equal to $100 \%$ (in fact no member of the company organs, neither manager nor company employee, may receive a bonus greater than their fixed remuneration). There may be exceptions to this limit only under the following conditions:

(i) that the faculty of exception is contained in the Statute (so the favourable opinion of the Extraordinary Meeting is required);

(ii) that the effective exception is approved by the Ordinary Meeting (here is the volitional power of the Meeting alluded to above);

(iii) that in any case the relationship between fixed and variable remuneration remains within the "reinforced cap" of $200 \%$.

The innovation is fairly disruptive compared with the previous regulatory system which, instead, was limited to fixing the more general principle, in any case maintained for non-relevant personnel, of "appropriate balancing" between fixed and variable components.

So for the first time a change of direction is formalized with regard to the need for alignment between shareholder's interests and manager's remuneration, as alluded to previously. The provision then tends towards a limitation of variable remuneration, favouring de facto a system which is scarcely incentivizing (but precisely for this reason, with less risk appetite) (Becht, Bol-

reflect all the risks to which the body or group is or may be exposed. This should furthermore permit the bodies to provide for, in their remuneration policy, suitable incentives to ensure prudent behaviour on the part of personnel, and should guarantee that identification of personnel whose professional activities have a substantial impact on the body's risk profile reflects the risk level of the various activities within the body." 
ton, Röell, 2011), and which thus stands to protect the suitability of compensation, in fact countering a notable tendency to assign variable emoluments in a measure often disproportionate to the total (Ferrarini, Ungureanu, 2014).

With reference to the variable proportion of remuneration, the competent company organs" are responsible for choosing the remuneration formula, the amount and the incentivizing scheme most appropriate to its needs. But, the Provision is concerned that this component should effectively be: (i) correlated to company results; (ii) risk sensitive, also in the medium term. And hence the formalization of a series of forecasts in this sense.

Variable remuneration must be first and foremost sustainable under the financial and assets and liabilities profile. To make it so, it is therefore necessary to provide "entry gates" without respect for which no bonuses can be paid. The regulations do not deal with formalizing these gates, but by now it is normal practice among banks to refer to indicators of liquidity (e.g. level of counterbalancing capacity, or of "readily liquidable assets"), assets and liabilities (among which CET 1 Ratio, Total Capital Ratio, Level of Absorbed Internal Capital) and performances (among others, result of business year net of extraordinary components); the fixing of these indicators must be coherent with the levels of "risk appetite" and "risk tolerance" established preliminarily and passed by the Board, as well as with the bank's strategic and operational planning documents ${ }^{8}$.

When the conditions of access to bonuses are achieved and verified, the bank must make sure of the effective correlation with company performance parameters ${ }^{9}$. In the calibration of such parameters there should of course be coherency between these measurements and the need for measuring an effective level of performance, as much as possible "normalized", "standardized" and "risk adjusted".

All these forecasts have to do with so-called ex-ante risk adjustment, that is to say they are linked to the need for a functional bond between bonus and performance (direct link) and bonus and risks assumed (inverse link). But the regulations also and above all provide for elements of ex-post risk adjustment aiming at guaranteeing that the links described are maintained over time. In this way going against managements which, though optimal in the short term inasmuch as they are suitable for increasing the value of performance indices (to which emolument is anchored: e.g. quotations or data of the balance) and thus maximizing the amount receivable, may not be so in the long term at all, involving an excessive assumption of risks (Laverty, 1996).

\footnotetext{
${ }^{8}$ On the concept of risk appetite see AIFIRM documents (Associazione Italiana Financial and Industrial Risk Manager) (http://www.aifirm.it/il_risk_appetite_framework/), as well as the Bank of Italy Circolare $\mathrm{N}^{\circ} 263$ of $27^{\text {th }}$ December 2006 and subsequent updates.

9 The regulations suggest, as possible parameters of "connection with company performances", RORAC, RAROC and RARORAC.
} 
With view then to aligning incentives with the long term interests of the bank, the financial instruments assigned to the most relevant personnel are subject, first of all, to a prohibition against selling (e.g. with lock-in clause) until an adequate period of time has elapsed (retention period), identified and defined by the bank on the basis of suitable criteria (Section III, Paragraph $2)^{10}$.

In line with the regulatory system previously in force, the deferment of the variable remuneration is moreover obligatory for a period between 3 and 5 years and for a percentage of remuneration "between $40 \%$ and $60 \%$ ", with the purpose of guaranteeing effectiveness of the link between remuneration and long term results, and avoiding that management choices may be influenced by speculative factors.

The provisions concerning deferral take substance in the obligation to provide for malus clauses (meaning non-payment of all or part of the deferred variable remuneration on ascertainment of certain elements of risk) and for clawback (clauses for return of all or part of the variable remuneration already paid out); the intention is clearly to discourage opportunistic behaviour aimed at obtaining short term company results, harbinger of the manifestation of future risks (the already mentioned short-termism) (Clementi et al., 2009). For schematization requirements the methods by which the bonuses in question are paid could also come under the forecasts of ex-post risk adjustment. And here lies the explanation of the provision for which at least half of the variable remuneration must be paid in shares (or other capital instruments) subject to a retention period of at least two years. In fact the rule, having defined the method of paying bonuses, also deals with definition of the means of exchange by which they are to be paid. These means of exchange are identified as those financial instruments that reflect company market values. The retention period would moreover guarantee that this collection is not univocally induced by short term observation, or worse still, influenced by speculative factors ${ }^{11}$.

Then there are new items in comparison with the Provision of $30^{\text {th }}$ March 2011 - Provision concerning policies and practices of remuneration

\footnotetext{
${ }^{10}$ The rule variously defines the (minimum) duration of this retention period according to the category and characteristics of the intermediary: the minimum term is two years for the major banks and at least one year for the intermediate. This expectation, in comparison with the past when the period could be determined autonomously, limits the negotiating autonomy of the parties (the bank first and foremost) (Bentivegna, 2016).

${ }^{11}$ Instruments admissible as balancing (at $50 \%$ ) of variable remuneration, paid by liquid funds, are dealt with in Delegated Regulation EU N ${ }^{\circ} 527 / 2014$ of $12^{\text {th }}$ March 2014. It should also be remembered that the majority doctrine is in agreement on the fact that realignment of the manager's interests, to be pursued (also) through suitable remuneration policies, must be implemented not only with regard to the shareholder but also to the other stakeholders. Hence the requirement that balancing the quota of liquid remuneration funds should not be effected only through the granting of shares but also of other instruments admissible for the purpose.
} 
and incentivizing in banks and banking groups, issued by the Bank of Italy ${ }^{12}$ in relation to the proportion of remuneration having to do with the final moment of the work relationship, or the moment succeeding it. These are provisions for early severance payments, better known as golden parachutes, and for discretional pension benefits. In both cases these particular benefits must be connected with company performances, subject to the period of deferral, and to the abovementioned malus and clawback clauses. The clear intention is to discourage opportunistic behaviour, also with manifestation of risks subsequent to the conclusion of the respective work relationships (or positions as company officers) by the beneficiaries of the abovementioned remuneration benefits.

Lastly, the regulations envisage special obligations regarding the remuneration of particular company positions. The Chairman of the Organ with Function of Strategic Supervision (which is to say the chairman of the board of directors in the traditional or monistic system, or the chairman of the supervisory council in the dualistic system) is for example subject to a twofold cap: his total remuneration cannot in fact exceed the fixed remuneration of the MD or the General Manager. Again, the Provision requires by rule the avoidance of incentivizing mechanisms for non-executive administrators (including the Chairman), while their use for members of the Board of Arbitrators is expressly forbidden, as indeed indicated in the Italian Civil Code. Heads of the functions of internal control (compliance, risk management and internal auditing) may instead receive bonuses, as long as the latter do not exceed one third of fixed remuneration (reinforced cap) and as long as they are linked solely to objectives of company sustainability (cost containment, assets reinforcement) and never to performance objectives.

On this point it is interesting to note how the Provision in question creates a close and coherent interconnection with prescriptions on the subject of "Company Governance" (Circolare 285, Update I of May 2014) and of "System of Internal Controls" (Circolare 263, 15 ${ }^{\text {th }}$ Update, today integrated into Circolare 285 itself) issued by the Bank of Italy in the same period.

By way of example, just as the discipline of "Bank Governance" requires that the Chairman of the Board of Directors should play a role of guarantor, the Provision limits the payment of a bonus, evidently freeing his remuneration from elements of performance which do not sit well with such a role. The same goes for the "non-executive" administrators, in keeping with the principle, of Anglo-Saxon derivation, which requires, in favour of the board dialectic and the balancing of powers internal to the corporate administrative organ, a dualism between executive directors (to whom are attributed management authority, and therefore specific remunerations) and non-executive (for

\footnotetext{
${ }^{12}$ With which Directive 2010/76/EU (CRD III) had been implemented.
} 
whom, quite clearly, high bonuses would conflict with the role - exercised for example within governance committees - of high supervision over delegated management). In the same way the limitation of bonuses in favour of heads of internal control systems is coherent with that organizational balance which would have the functions in question, not by accident reporting directly to the board, as internal subjects deputised to control of company management through the concentric and stratified definition of internal control. And lastly, the prohibition of variable bonuses in favour of the members of the board of arbitrators is a matter of good sense, more than one of regulatory coherence.

\section{Empirical Analysis}

In the theoretical-regulatory picture delineated so far, the empirical analysis presented in this paper proposes to analyse and compare the remuneration policies adopted, over a determined period, by a suitably selected sample of significant supervised subjects ${ }^{13}$.

As stated above, it is a preliminary inquiry which, albeit with the intrinsic limitations related to sample size and to the reference period and context, is aimed at obtaining a first result which will be followed by future research efforts.

To test the research hypothesis, the sample was selected considering the 3 "significant" Italian banks for total activity, as resulting from the definition as per article 2, points 16) and 22) of the framework regulations on the Single Supervisory Mechanism (SSM). In particular they are UniCredit S.p.A. (total assets between 500 and 1000 billion Euros), Intesa Sanpaolo S.p.A. (total assets between 500 and 1000 billion Euros) and Banca Monte dei Paschi di Siena S.p.A. (total assets between 150 and 300 billion Euros) (ECB, 2017) ${ }^{14}$.

\footnotetext{
${ }^{13}$ By "significant supervised subject" is intended a) a significant supervised subject in a member State of the euro area, or b) a significant supervised subject in a participating member State not belonging to the euro area. By "significant supervised group" is intended a group supervised which is qualified as a significant supervised group in accordance with a decision by the ECB adopted on the basis of article 6 , paragraph 4 , or of article 6 paragraph 5 , letter b) of EU Regulation $N^{\circ} 1024 / 2013$ of the council of $15^{\text {th }}$ October 2013 , which attributes to the ECB special duties regarding policies on the subject of prudential supervision of credit institutes (regulation on SSM), Cf. OB L 287 of 29.10.2013, p. 63. The assessment of significance is based on criteria such as: the overall value of their activity, the importance of the economy of the country where they operate or in the EU as a whole, the scale of their trans-frontier activities, and whether they have requested or received public financial assistance from the European Stability Mechanism or from the European Financial Stability Facility (EFSF).

${ }^{14}$ The selection criteria for the sample adopted in this paper is the same one utilized in analogous sectorial studies, such as for example the one carried out by Mediobanca (thirteenth investigation of major international banks effected by Mediobanca for the year 2016), according to which, "to be part of the sample the companies must represent a significant share of the total aggregate of the balance assets of the respective economic area. This significant nature is defined by adding companies to the sample until their contribution exceeds one percent of
} 
The periods of reference for the analysis are 2013 and 2015, which represent respectively the year before and the year after the Provision coming into force.

\section{Methodology}

In observation of the informative obligations as per Art. 123-ter of the TUF (Single Text on Financial Intermediation) and those deriving from the discipline issued for the banking sector, banks are obliged to publish a report on remuneration which illustrates the company's policies regarding remuneration of the members of the administration organs, of the general managers and of managers with strategic responsibilities. Such a report supplies an adequate representation of each of the items comprising it, analytically illustrating remuneration paid during the reference business year by the company and by controlled or associated companies.

That data used for drawing up this study have been gathered manually for each of the banks analysed, on the basis of the remuneration reports, of the reports on corporate governance, of the information sheets for the public (socalled Pillar 3) and the minutes of the meetings for the years 2013, 2014, 2015 and 2016.

The results of the analysis, point by point, are shown below and find a synthetic representation in the tables at the end of this document.

\section{Results \\ Relevant personnel}

'Relevant personnel', as defined by Circolare 285, includes "the categories of subjects whose professional activity has or may have an important impact on the bank or banking group's risk profile".

In 2015 the population of the most relevant personnel was reviewed by the 3 sample banks, guaranteeing full respect for the regulatory provisions. The result of the assessment process for identification of the "material risk takers" led to the singling out, for the year 2015, of a total number of resources no less than five times greater than the pre-reform period (Table 2).

\section{Remuneration received and relationship between fixed and variable compo- nent}

The tables from 1a to 1d show the fixed and variable remunerations paid on average to the organs of administration, control and management in the two reference periods.

the previous aggregate cumulative total of the balance assets; banks whose contribution is less than one percent of this aggregate are excluded". 
From he analysis it emerges that the remuneration of the MDs of the sample banks underwent a slight diminution (in fact the growth rate is equal to $-8.64 \%$ ). In particular the fixed remunerations decreased while there was an increase in bonuses (in this sense a strong augmenting of the fair value of remuneration represented by shares in capital).

The remuneration of the Chairmen of the Boards instead increased for the Unicredit group and Monte dei Paschi di Siena, similarly the non-monetary benefits, whereas the remuneration of the Chairman of the Management Council of Intesa San Paolo decreased (Table 1f). In any case, in conformity with the Supervisory Provisions on remuneration, that of the Chairman is less than the fixed remuneration received by the MD and the CEOs.

Remuneration of the organs of control diminished while that of general managers and other management with strategic responsibilities were on the increase (Tables 1c and 1d).

The limits were instead respected regarding the relationship between fixed and variable components of remuneration: all the sample banks remain within the $100 \%$ (with the exception of up to $200 \%$ for Unicredit and Intesa San Paolo for special categories of personnel). So the principle is now formalized by which no member belonging to most relevant personnel may receive a bonus greater than the fixed quota of their remuneration; moreover, already prior to the Provisions in force the banks employed "shrewd" limitations to the incentivizing quota of remunerations (Table 3).

\section{Entry Gates}

The regulations establish that "subordination of bonus payment to objectives of company sustainability is admissible" (e.g. cost containment, reinforcement of capital etc.). To this end conditions of access to variable and not recurrent remuneration (so-called entry gates) are envisaged which prevent payment in whole or in part.

The three banks analysed have prescribed, since before the recent regulatory update, limiting conditions for bonus payments, these tending to be subordinate to the achievement of minimum thresholds in terms of assets (Common Equity Tier $1^{15}$ ), liquidity (Liquidity Coverage Ratio and Net Stable

\footnotetext{
15 The governing regulations regarding prudential requisites for credit institutes and investment firms is concerned with guaranteeing that financial intermediaries possess their own funds in sufficiency to absorb risks deriving from carrying out their activities.

The general principle is: the greater the riskiness of the activity assumed, the greater the possessed funds must be. To this end: (i) own funds are classified in three categories: Common Equity Tier 1 or CET 1, Additional Tier 1 or AT 1 and Tier 2 on the basis of their capacity to take part in the institute's risks of loss; (ii) a minimum obligatory coefficient of own funds that the institute must possess is prescribed.

Among the obligatory minimum coefficients, CET 1 consists of instruments of primary capital class 1 , net of prudential filters and detractions.
} 
Funding Ratio ${ }^{16}$ ) and profitability (absence of losses, or current positive result before Taxes). The thresholds vary for the 3 banks under consideration (Table 4).

In 2015 the threshold prescribed by the implementation rules for the bonus pool was reached in the case of the 3 banks under analysis.

\section{Malus and Clawback Mechanisms}

The variable component is moreover subject, on the basis of the regulations in force, to ex-post correction mechanisms (malus and clawback) designed, among other things, to reflect the levels of assets and performance net of risks effectively assumed (or undergone), as well as to take account of individual behaviour by personnel under survey. These mechanisms may therefore lead to reduction (or zeroing) of the variable remuneration itself, especially in the case of results significantly inferior to predetermined objectives.

The banks then introduced indicators of a qualitative nature, linked to the conduct of personnel in the course of their work relationship (in general, cases of disciplinary measures for fraudulent behaviour or gross negligence by personnel, also taking account of profiles of a legal, national insurance and tax nature on the subject), which are specifically designed to activate the mechanisms of clawback (return of already paid sums).

From the analysis of company documents it emerged that, given the assets and performance levels achieved, and considering the behaviour of personnel during 2014, for the 3 sample banks it was not considered necessary to apply any of these mechanisms in 2015 (Table 5).

\section{Period of deferral}

As far as the periods of deferral are concerned, the regulations appear to have affected only the period of deferment envisaged for the most relevant personnel (increase from 3 to 5 years for the banks Intesa and MPS), leaving unvaried the provisions for non-relevant personnel. After the introduction of

The instruments of CET 1, in particular, are those capable of absorbing the first and greatest part of possible losses sustained by the institute of credit. The regulations therefore provide for a series of conditions that these instruments must respect from the formal and economic viewpoint to guarantee both this capacity and their stability over time (Rutigliano 2016).

${ }^{16}$ The new rules of prudential supervision established by Basel 3 envisage the calculation of two liquidity indicators and minimum limits to respect, equal to $100 \%$ of the indicator itself: a short-term indicator, the Liquidity Coverage Ratio, and a structural indicator, the Net Stable Funding Ratio.

The former is aimed at the establishment of a liquidity buffer that allows the bank to survive 30 days of potential net cash outflows in stress situations, be they idiosyncratic (specific to the individual bank) or systematic (proper to the whole financial system).

The latter aims instead to tackle structural unbalances in the composition of the assets and liabilities balance sheet over the timespan of one year (Rutigliano, 2016). 
the Provision, therefore, the variable compensation was deferred 5 years for executive directors, the general manager, the general co-managers, the general vice-managers (and other analogous figures), the heads of main business areas (and areas with greater risk profile, e.g. investment banking), company functions or geographical areas, as well as those reporting directly to organs with functions of strategic supervision, management and control. Whereas for the others deferral it was 3 years (Table 6).

\section{Golden Parachute}

As regards remuneration agreed upon the event of early termination of the mandate or early resignation (so-called golden parachute), the new regulations do not seem to have brought modifications of note.

The trend, at least in recent years, is in fact to not envisage treatment in favour of administrators in the case of early termination of work relationship (Table 7).

Whereas any agreements scheduled with Executive Managers are governed by the normal provisions of law (e.g. the individual contract as Manager signed by the Unicredit Group MD prescribes that the indemnity to be paid in the event of resignation or dismissal/revocation without just cause is constituted: (i) by the fixed remuneration, (ii) by every other remuneration of a continuative nature and (iii) by the average of variable remunerations paid over the last three years prior to termination.

In the light of the results obtained, hypothesis H1) is therefore also confirmed: the regulations do not modify, except marginally, the banks' remuneration and incentivizing systems. In fact, the most relevant modifications concerned the insertion of limits to the relationship between the fixed and variable components of remuneration, the introduction of qualitative indicators linked to the conduct of personnel in the course of their work relationship, such as might trigger mechanisms of clawback, and, the forecast of a longer period of deferral of the variable component of remuneration, for the relevant personnel.

\section{Conclusion and possible further developments of the research}

As may be seen from the foregoing paragraphs, also after appropriate comparison with the tables below, the three main Italian groups turn out to be (i) in conformity with full application, since 2015, of the supervisory prescriptions contained in the Provision; (ii) not particularly influenced, as regards the architecture of their remuneration system, by the regulatory innovations introduced in 2014. The explanation for this phenomenon is traceable to multiple aspects, chiefly deriving from a general cultural approach of care and attention, by our country's banking system, with regard to risk factors inherent in an unbalanced remuneration and incentivizing system. On this subject, the 
banks analysed demonstrate how, as early as the business year 2013, their systems of paying top management were geared to a suitable balancing of the fixed and variable components of remuneration, as well as to cogent systems (ex-ante and ex-post) for adjustment of the latter. In truth, the Provisions issued in 2014 and here examined follow" the conceptual itinerary of numerous previous Provisions issued by the Bank of Italy in earlier years (in particular the cited provision of $30^{\text {th }}$ March 2011), thus seeking to implement a system of principles already in place. Nonetheless, by analysing the most innovative part of the provision, which is the part relating to the "cap" between fixed and variable remuneration, we note a greater moderation in the variable remuneration of certain figures. Furthermore, the sample of selected banks was already in conformity regarding that which then became cogent with the new provisions. In fact, as may be seen from the more precise disclosure reports on limitation of bonuses as against payments of a fixed nature, they have, more than anything else, rendered obligatory a greater formalisation and standardisation of principles already accepted in the past.

In this general framework the data of the three banks examined show a real effect produced by the new regulations: a widening of the perimeter enclosing subjects who may be qualified as "risk takers".

The results of the research presented here highlight some important profiles of governance of the leading banking groups. However, they suffer from the limitations indicated at the beginning, such as narrowness of the sample, the short period of reference and the absence of comparisons at European and international level. The research reported in this paper, as observed preliminarily, should be considered introductory and preparatory to a broader research design aimed at the so-called traditional generalization of results through a longitudinal type analysis, based on the variations in time of the same samples, or through consideration of wider ranging samples belonging to economic and cultural contexts different from our national one.

\section{References:}

1. Accornero M., Alessandri P., Carpineli L., Sorrentino A.M. (2017). Non-performing loans and the supply of bank credit: evidence from Italy, Questioni di Economia e Finanza (Occasional Papers), 374.

2. AIFIRM, http://www.aifirm.it/il_risk_appetite_framework/.

3. BCE (2017), "Full List of supervised entities (as of 1 January 2017)", https://www.bankingsupervision.europa.eu/ecb/pub/pdf/list_of_supervised_entities_201701.en.pdf?fa67031bce20d0ce07da37a4c0685435. 
4. Bebchuk L., Fried J. (2003). Executive Compensation as an Agency Problem, Journal of Economic Perspectives, 17 (3), 71-92.

5. Bebchuck L., Fried J. (2004). Pay without performance. The unfulfilled promise of executive compensation, Harvard university Press, 2004.

6. Becher D. A., Campbell Ii T. L., Frye M. B. (2005). Incentive Compensation for Bank Directors: The Impact of Deregulation, The Journal of Business, 78 (5), 1753-1778.

7. Becht M., Bolton P., Roell A., (2011). Why bank governance is different, Oxford Review of Economic Policy, 27 (3), 437-463.

8. Bentivegna A. M. (2016). Un nuovo intervento sulla disciplina delle politiche di remunerazione e incentivazione nelle banche, Minerva Bancaria, 1, 47-82.

9. Berle A. A., \& Means G. C. (1932). The modern corporation and private property, New York: Commerce Clearing House.

10. Bolton P., Scheinkman J., Xiong W. (2006). Executive compensation and short-termist behaviour in speculative markets, The Review of Economic Studies, 73 (3), 577-610.

11. Hope O., Thomas W. B. (2008). Managerial empire building and firm disclosure, Journal of Accounting Research, 46 (3), 591-626.

12. Choi A. (2004). Golden parachute as a compensation-shifting mechanism, Journal of Law, Economics, and Organization, 20 (1), 170-191.

13. Circolare Banca d'Italia n. 263, 15.mo aggiornamento.

14. Circolare Banca d'Italia n. 285 del 17 dicembre 2013, VII Aggiornamento.

15. Circolare Banca d'Italia n. 285, I Aggiornamento del Maggio 2014.

16. Clementi G. et al. (2009). Rethinking compensation in financial firms, Restoring financial stability: How to repair a failed system, 197-214.

17. Commission Delegated Regulation (EU) N. 527/2014, of 12 March 2014, Official Journal of the European Union L 148/21, of 20 May 2014.

18. Commission Delegated Regulation (EU) N. 604/2014, of 4 March 2014, Official Journal of the European Union L 167/30, of 6 June 2014.

19. Commission Recommendation (EU) of 30 April 2009, GU L 120/22, of 15 May 2009.

20. Core J.E., Guay W., Larcker D.F. (2001). Executive Equity Compensation and Incentives: A Survey, Working Paper, Wharton School.

21. Core J.E., Holthausen R.W., Larcker D.E. (1999). Corporate Governance, Chief Executive Compensation and Firm Performance" Journal of Financial Economics, 51, 371-406.

22. Council Regulation (EU) N. 1024/2013, of 15 October 2013, Official Journal of the European Union L 287/63, of 29 October 2013. 
23. Dallas, L. (2011). Short-termism, the financial crisis, and corporate governance, Journal of Corporation Law, 284-285.

24. Demsetz H., Villalonga B. (2001). Ownership structure and corporate performance, Journal of Corporate Finance, 7 (3), 209-233.

25. De Poli M. (2013). Executives' Compensations According to the Bank of Italy, Riv. dir. banc., dirittobancario.it, 5, 2013.

26. Direttiva 2013/36/UE del Parlamento Europeo e del Consiglio, del 26.06.2013 (c.d. CRD IV), cfr. GU L 176, del 27.026.2013, 338.

27. Duffhues P., Kabir R. (2008). Is the pay-performance relationship always positive?: Evidence from the Netherlands, Journal of Multinational Financial Management, 18 (1), 45-60.

28. Fama E.F. (1980). Agency Problems and the Theory of the Firm, Journal of Political Economy, 88 (2), 288-307.

29. Ferrarini G., Ungureanu M.C. (2014). Executive Remuneration, A comparative overview, Law working paper 268.

30. Furlan G., Cremascoli M., Paglionico C. (2011). Banche: politiche di remunerazione e incentivazione, Diritto e Pratica del lavoro, 11, 643.

31. Holmstrom B. (1979). Moral Hazard and Observability, The Bell Journal of Economics, 10 (1), 74-91.

32. Hubbard R. G., Palia D. (1995). Executive pay and performance Evidence from the U.S. banking industry Original, Journal of Financial Economics, 39 (1), 105-130.

33. Intonti M. (2011). Crisi finanziaria e politiche di remunerazione nelle banche. Note a margine del volume Intermezzo. Tre anni di crisi bancarie del prof. R. Ruozi, Banche e banchieri, 2, 130-142

34. Jensen M. C., Meckling W. H. (1976). Theory of the firm: Managerial behavior, agency costs and ownership structure, Journal of Financial Economics, 3 (4), 305-360.

35. Kanniainen V. (2000). Empire building by corporate managers: the corporation as a savings instrument, Journal of Economic Dynamics and Control, 24 (1), 127-142.

36. Lambert R.A., Larker D.F. (1985). Executive Compensation Contracts, Executive Decision-Making and Shareholder Wealth: A Review of Evidence, Midland Corporate Finance Journal, 2 (4), 6-22.

37. Laverty K. J. (1996). Economic “short-termism”: The debate, the unresolved issues, and the implications for management practice and research, Academy of Management Review, 21 (3), 825-860.

38. Livne G., Markarian G., Milne A. (2011). Bankers' compensation and fair value accounting, Journal of Corporate Finance, 17 (4), 10961115.

39. Mediobanca (2016). Dati cumulativi delle principali banche internazionali e piani di stabilizzazione finanziaria. Indagine annuale 
sulle principali banche aventi sede in Europa, Giappone, Stati Uniti e Cina.

40. Murphy K.J. (1985). Corporate performance and managerial remuneration: An empirical analysis, Journal of Accounting and Economics, 7 (1-3), 11-42.

41. Murphy K.J. (1999). Executive Compensation, Orley Ashenfelter and David Card (eds.), North Holland, Handbook of Labor Economics, 2485-2563.

42. Nigro A. (2014). La remunerazione degli amministratori e degli alti dirigenti delle banche, La governance delle società bancarie, 37 .

43. Provvedimento Banca d'Italia del 30 marzo 2011, Bollettino di Vigilanza n. 3, marzo 2011.

44. Regulation (EE) n. 468/2014 of the European Central Bank, of 16 April 2014, Official Journal of the European Union L 141/1, of 14 May 2014.

45. Rutigliano M. (2016). Il bilancio della banca e degli altri intermediari finanziari, Milano, Egea.

46. Shlomo B., Wolfgang Eggert J., Nguyen T., (2013). Regulation of remuneration policy in the financial sector: Evaluation of recent reforms in Europe, Qualitative Research in Financial Markets, 5 (3), 256-269.

47. Sloan R.G., (1993). Accounting earnings and top executive compensation, Journal of Accounting and Economics, 55-100.

48. Vitali M. L., Miramondi M. (2014). La remunerazione degli amministratori di società quotate tra equilibrio degli interessi in gioco e assetti proprietari concentrati, Rivista di Diritto Bancario, 4, 1-14. 


\section{APPENDIX}

\section{Tables}

\section{Remuneration of high governance organs}

TABLE 1a - REMUNERATION OF MEMBERS OF BANK MANAGEMENT ORGANS (IN EUROS)

\begin{tabular}{|c|c|c|c|c|c|c|c|c|c|c|c|c|c|c|c|c|c|c|}
\hline Year & $\begin{array}{c}\text { Average Fixed } \\
\text { Remunerations }\end{array}$ & $\Delta \%$ & \begin{tabular}{c|} 
Average \\
Remunerations \\
for participation \\
in committees
\end{tabular} & $\Delta \%$ & $\begin{array}{c}\text { Average Bonuses } \\
\text { and other } \\
\text { incentives }\end{array}$ & $\Delta \%$ & $\begin{array}{l}\text { Average Share } \\
\text { in profits }\end{array}$ & $\Delta \%$ & $\begin{array}{l}\text { Average Non- } \\
\text { monetary } \\
\text { Benefits }\end{array}$ & $\Delta \%$ & $\begin{array}{l}\text { Average Other } \\
\text { remunerations }\end{array}$ & $\Delta \%$ & Total & $\Delta \%$ & $\begin{array}{l}\text { Average Fair } \\
\text { Value of equity } \\
\text { remunerations }\end{array}$ & $\Delta \%$ & $\begin{array}{c}\text { Average end of } \\
\text { mandate or } \\
\text { severance } \\
\text { indemnity }\end{array}$ & $\Delta \%$ \\
\hline 2013 & $6,013,946.67$ & - & $76,836.33$ & - & $498,000.00$ & - & 0.00 & - & $324,050.33$ & - & $298,731.67$ & - & $7,211,565.00$ & - & $459,495.33$ & - & $1,200,000.00$ & - \\
\hline 2015 & $5,151,908.00$ & -14.33 & $96,315.00$ & 25.35 & $710,666.67$ & 42.70 & 0.00 & - & $210,762.67$ & -34.96 & $418,777.00$ & 40,19 & $6,588,429.33$ & $-8,64$ & $1,729,590.67$ & 276.41 & 0,00 & -100.00 \\
\hline
\end{tabular}

TABLE 1b - REMUNERATION OF MEMBERS OF BANK CONTROL ORGANS (IN EUROS)

\begin{tabular}{|c|c|c|c|c|c|c|c|c|c|c|c|c|c|c|c|c|c|c|}
\hline Year & $\begin{array}{l}\text { Average Fixed } \\
\text { Remunerations }\end{array}$ & $\Delta \%$ & \begin{tabular}{|c|} 
Average \\
Remunerations \\
for participation \\
in committees
\end{tabular} & $\Delta \%$ & $\begin{array}{c}\text { Average Bonuses } \\
\text { and other } \\
\text { incentives }\end{array}$ & $\Delta \%$ & $\begin{array}{l}\text { Average Share } \\
\text { in profits }\end{array}$ & $\Delta \%$ & $\begin{array}{c}\text { Average Non- } \\
\text { monetary } \\
\text { Benefits }\end{array}$ & $\Delta \%$ & $\begin{array}{l}\text { Average Other } \\
\text { remunerations }\end{array}$ & $\Delta \%$ & Total & $\Delta \%$ & $\begin{array}{l}\text { Average Fair } \\
\text { Value of equity } \\
\text { remunerations }\end{array}$ & $\Delta \%$ & $\begin{array}{c}\text { Average end of } \\
\text { mandate or } \\
\text { severance } \\
\text { indemnity }\end{array}$ & $\Delta \%$ \\
\hline 2013 & $2,011,318.67$ & - & $38,066.67$ & - & 0.00 & - & 0.00 & - & $13,125.67$ & - & $36,738.00$ & - & 2,099,249.00 & - & 0.00 & - & 0.00 & - \\
\hline 2015 & $1,715,876.00$ & -14.69 & 0.00 & -100.00 & 0.00 & - & 0.00 & - & $15,857.33$ & 20.81 & $20,900.00$ & -43.11 & $1,752,633.33$ & -16.51 & 0.00 & - & 0.00 & - \\
\hline
\end{tabular}

TABLE 1C- REMUNERATIONS OF BANK MANAGERS WITH STRATEGIC RESPONSIBILITIES (IN EUROS)

\begin{tabular}{|c|c|c|c|c|c|c|c|c|c|c|c|c|c|c|c|c|c|c|}
\hline Year & $\begin{array}{l}\text { Average Fixed } \\
\text { Remunerations }\end{array}$ & $\Delta \%$ & $\begin{array}{c}\text { Average } \\
\text { Remunerations } \\
\text { for participation } \\
\text { on committees }\end{array}$ & $\Delta \%$ & $\begin{array}{c}\text { Average Bonuses } \\
\text { and other } \\
\text { incentives }\end{array}$ & $\Delta \%$ & $\begin{array}{c}\text { Average Share } \\
\text { in profits }\end{array}$ & $\Delta \%$ & $\begin{array}{c}\text { Average Non- } \\
\text { monetary } \\
\text { Benefits }\end{array}$ & $\Delta \%$ & $\begin{array}{l}\text { Average Other } \\
\text { remunerations }\end{array}$ & $\Delta \%$ & Total & $\Delta \%$ & $\begin{array}{c}\text { Average Fair } \\
\text { Value of equity } \\
\text { remunerations }\end{array}$ & $\Delta \%$ & $\begin{array}{c}\text { Average end of } \\
\text { mandate or } \\
\text { severance } \\
\text { indemnity }\end{array}$ & $\Delta \%$ \\
\hline 2013 & $5,302,318.33$ & - & 0.00 & - & $900,347.00$ & - & 0.00 & - & $330,890.33$ & - & $238,847.67$ & - & $6,772,403.33$ & - & $273,543.00$ & - & $2,096,501.33$ & - \\
\hline 2015 & $5,960,209.00$ & 12.41 & 0.00 & - & $1,606,541.67$ & 78.44 & 0.00 & - & $519,823.67$ & 57.10 & $431,947.33$ & 80.85 & $8,518,521.67$ & 25,78 & $3,633,092.00$ & 1228.16 & $2,783,183.33$ & 32.75 \\
\hline
\end{tabular}


TABLE 1d - REMUNERATIONS OF BANK GENERAL MANAGERS (IN EUROS)

\begin{tabular}{|c|c|c|c|c|c|c|c|c|c|c|c|c|c|c|c|c|c|c|}
\hline Year & $\begin{array}{l}\text { Average Fixed } \\
\text { Remunerations }\end{array}$ & $\Delta \%$ & \begin{tabular}{c|} 
Average \\
Remunerations \\
for participation \\
on committees
\end{tabular} & $\Delta \%$ & $\begin{array}{c}\text { Average Bonuses } \\
\text { and other } \\
\text { incentives }\end{array}$ & $\Delta \%$ & $\begin{array}{l}\text { Average Share } \\
\text { in profits }\end{array}$ & $\Delta \%$ & $\begin{array}{c}\text { Average Non- } \\
\text { monetary } \\
\text { Benefits }\end{array}$ & & $\begin{array}{l}\text { Average Other } \\
\text { remunerations }\end{array}$ & $\Delta \%$ & Total & $\Delta \%$ & $\begin{array}{c}\text { Average Fair } \\
\text { Value of equity } \\
\text { remunerations }\end{array}$ & $\Delta \%$ & $\begin{array}{c}\text { Average end of } \\
\text { mandate or } \\
\text { severance } \\
\text { indemnity }\end{array}$ & $\Delta \%$ \\
\hline 2013 & $1,011,346.67$ & - & $5,400.00$ & - & 0.00 & - & 0.00 & - & $104,579.67$ & - & $4,621.00$ & - & $1,125,947.33$ & - & $91,391.67$ & - & $150,000.00$ & - \\
\hline 2015 & $1,155,334.67$ & 14.24 & 0.00 & -100.00 & $116,666.67$ & - & 0.00 & - & $101,563.33$ & -2.88 & $97,031.67$ & 1999.80 & $1,470,596.33$ & 30.61 & $319,699.67$ & 249.81 & $1,797,897.00$ & 1098.60 \\
\hline
\end{tabular}

TABLE 1e - REMUNERATIONS OF BOARD CHAIRMAN, UNICREDIT (IN EUROS)

\begin{tabular}{|c|c|c|c|c|c|c|c|c|c|}
\hline Year & $\begin{array}{c}\text { Emoluments passed } \\
\text { by the meeting }\end{array}$ & $\begin{array}{l}\text { Attendance } \\
\text { allowances }\end{array}$ & $\begin{array}{c}\text { Remunerations ex } \\
\text { Art. 2389 }\end{array}$ & $\begin{array}{c}\text { Total Fixed } \\
\text { Remunerations }\end{array}$ & $\begin{array}{c}\text { Remunerations for } \\
\text { participation on } \\
\text { committees }\end{array}$ & $\begin{array}{c}\text { Bonuses and other } \\
\text { incentives }\end{array}$ & $\begin{array}{c}\text { Non-monetary } \\
\text { benefits }\end{array}$ & $\begin{array}{c}\text { Other } \\
\text { remunerations }\end{array}$ & Total \\
\hline 2013 & $161,000.00$ & $21,200.00$ & $1,375,000.00$ & $1,557,200.00$ & 0.00 & 0.00 & 0.00 & $-199,671.00$ & $1,357,529.00$ \\
\hline 2015 & $1,411,000.00$ & $22,000.00$ & $125,00 ., 00$ & $1,558,000.00$ & 0.00 & 0.00 & $12,906.0 \mathrm{c}$ & $10,792.00$ & $1,581,698.00$ \\
\hline
\end{tabular}

TABLE 1f - REMUNERATIONS OF CHAIRMAN OF MANAGEMENT BOARD, INTESA (IN EUROS)

\begin{tabular}{|c|c|c|c|c|c|c|c|c|}
\hline Year & $\begin{array}{c}\text { Fixed } \\
\text { remunerations }\end{array}$ & $\begin{array}{c}\text { Attendance } \\
\text { allowances }\end{array}$ & $\begin{array}{c}\text { Remunerations ex } \\
\text { Art. 2389 }\end{array}$ & Total & $\begin{array}{c}\text { Remunerations for } \\
\text { participation on } \\
\text { committees }\end{array}$ & $\begin{array}{c}\text { Bonuses and other } \\
\text { incentives }\end{array}$ & $\begin{array}{c}\text { Non-monetary } \\
\text { benefits }\end{array}$ & $\begin{array}{c}\text { Other } \\
\text { remunerations }\end{array}$ \\
\hline $\mathbf{2 0 1 3}$ & $1,033,000.00$ & 0.00 & 0.00 & $\mathbf{1 , 0 3 3 , 0 0 0 . 0 0}$ & 0.00 & 0.00 & 0.00 & 0.00 \\
\hline $\mathbf{2 0 1 5}$ & $900,000.00$ & 0.00 & 0.00 & $\mathbf{9 0 0 , 0 0 0 . 0 0}$ & 0.00 & 0.00 & 0.00 & 0.00 \\
\hline
\end{tabular}

TABLE 1g- REMUNERATIONS OF BOARD CHAIRMAN, MONTE PASCHI (IN EUROS)

\begin{tabular}{|c|c|c|c|c|c|c|c|c|}
\hline Year & $\begin{array}{c}\text { Fixed } \\
\text { remunerations }\end{array}$ & $\begin{array}{c}\text { Attendance } \\
\text { allowances }\end{array}$ & $\begin{array}{c}\text { Remunerations ex } \\
\text { Art. 2389 }\end{array}$ & Total & $\begin{array}{c}\text { Remunerations for } \\
\text { participation on } \\
\text { committes }\end{array}$ & $\begin{array}{c}\text { Bonuses and other } \\
\text { incentives }\end{array}$ & $\begin{array}{c}\text { Non-monetary } \\
\text { benefits }\end{array}$ & $\begin{array}{c}\text { Other } \\
\text { remunerations }\end{array}$ \\
\hline $\mathbf{2 0 1 3}$ & $69,600.00$ & 0.00 & 0.00 & $\mathbf{8 5 , 8 0 0 . 0 0}$ & $16,200.00$ & 0.00 & $1,810.00$ & 0.00 \\
\hline $\mathbf{2 0 1 5}$ & $326,889.00$ & 0.00 & 0.00 & $\mathbf{3 3 7 , 1 5 3 . 0 0}$ & $10,264.00$ & 0.00 & $3,896.00$ & $\mathbf{8 7 , 6 1 0 . 0 0}$ \\
\hline
\end{tabular}




\section{Identification of highly relevant personnel (material risk takers)}

\begin{tabular}{|c|l|c|c|}
\hline Year & \multicolumn{1}{|c|}{ UNICREDIT } & INTESA & MONTE DEI PASCHI DI SIENA \\
\hline $\mathbf{2 0 1 3}$ & $\begin{array}{l}\text { The reference population represents around } 0.1 \% \text { of overall } \\
\text { Group personnel }\end{array}$ & 26 \\
\hline $\mathbf{2 0 1 5}$ & $\begin{array}{l}1100 \text { (The reference population represents around } 0.7 \% \text { of } \\
\text { overall Group personnel, a datum in line with the process re- } \\
\text { sults 2014) }\end{array}$ & 350 \\
\hline
\end{tabular}

\section{Cap to variable remuneration quota}

\begin{tabular}{|c|c|c|c|}
\hline Year & UNICREDIT & INTESA & MONTE DEI PASCHI DI SIENA \\
\hline 2013 & $\begin{array}{l}\text { The incentivizing systems envisage maximum limits to vari- } \\
\text { able remuneration, whose target values are established by } \\
\text { considering the defined pay-mix where maximum effective } \\
\text { amount cannot exceed } 150 \% \text { of target value }\end{array}$ & $\begin{array}{l}\text { Limit to individual prize equal to } 100 \% \text { of gross annual re- } \\
\text { muneration }\end{array}$ & $\begin{array}{l}\text { Maximum limit of 500,000 euros to the overall Remunera- } \\
\text { tion of Top Management, starting from December } 2013 \\
\text { (post-Restructuration Plan 2013-2017) }\end{array}$ \\
\hline 2015 & $\begin{array}{l}\text { The maximum limit to variable remuneration was deter- } \\
\text { mined: } \\
\text { - at } 200 \% \text { of fixed remuneration for business functions } \\
\text { personnel; } \\
\text { at } 100 \% \text { for the rest of personnel, with the exception } \\
\text { of personnel belonging to the control functions }\end{array}$ & $\begin{array}{l}\text { The maximum limit to variable remuneration was deter- } \\
\text { mined: } \\
\text { at } 100 \% \text { of fixed remuneration for roles not belonging } \\
\text { to the Company Control Functions; } \\
\text { at } 33 \% \text { of fixed remuneration for roles belonging to } \\
\text { the Company Control Functions }\end{array}$ & $\begin{array}{l}\text { The maximum limit to variable remuneration was deter- } \\
\text { mined: } \\
\text { at } 100 \% \text { of fixed remuneration for roles not belonging } \\
\text { to the Company Control Functions; } \\
\text { at } 33 \% \text { of fixed remuneration for roles belonging to } \\
\text { the Company Control Functions }\end{array}$ \\
\hline
\end{tabular}




\section{Entry-Gates}

\begin{tabular}{|c|c|c|c|}
\hline Year & UNICREDIT & INTESA & MONTE DEI PASCHI DI SIENA \\
\hline 2013 & $\begin{array}{l}\text { Core Tier } 1 \text { Ratio } \geq 9 \% \text {. } \\
\text { Return on Tangible Equity } \geq 12.48 \% \\
\text { Group Net Profit }<0 \\
\text { In the case of loss, zeroing of incentive is activated } \\
\text { Cash Horizon } \geq 90 \text { days }\end{array}$ & $\begin{array}{l}\text { All incentivizing systems for Group personnel are subordi- } \\
\text { nate to three types of conditions: } \\
\text { 1. Common Equity Tier Ratio at least equal to the limit en- } \\
\text { visaged in the RAF (Risk Appetite Framework); } \\
\text { 2. Net Stable Funding Ratio (NSFR) at least equal to the } \\
\text { limit envisaged in the RAF; } \\
\text { 3. Absences of loss, or positive Current Result before tax } \\
\text { (net of extraordinary elements/elements deriving from repur- } \\
\text { chase of own balance-sheet items) }\end{array}$ & $\begin{array}{l}\text { Single GATE: } \\
\text { Group Consolidated Net Profit } \geq 50 \% \text { of Budget value }\end{array}$ \\
\hline 2015 & $\begin{array}{l}\text { erating Profit adjusted } \geq 0 \text {; } \\
\text { Net Profit } \geq 0 \text {; } \\
\text { Common Equity Tier } 1 \text { ratio transitional } \geq 7 \% \text {; } \\
\text { Cash Horizon } \geq 90 \text { days }\end{array}$ & $\begin{array}{l}\text { All incentivizing systems for Group personnel are subordi- } \\
\text { nate to three types of conditions: } \\
\text { 1. Common Equity Tier Ratio at least equal to the limit en- } \\
\text { visaged in the RAF (Risk Appetite Framework); } \\
\text { 2. Net Stable Funding Ratio (NSFR) at least equal to the } \\
\text { limit envisaged in the RAF; } \\
\text { 3. Absences of loss, or positive Current Result before tax } \\
\text { (net of extraordinary elements/elements deriving from repur- } \\
\text { chase of own balance-sheet items) }\end{array}$ & $\begin{array}{l}\text { Common Equity Tier } 1>10.2 \% \\
\text { Liquidity Coverage Ratio }>80 \% \\
\text { Profit Before Tax equal or superior to } 85 \% \text { of the budge } \\
\text { The percentage of prizes made available is a function of the } \\
\text { achievement percentages of a predefined Group Profit before } \\
\text { tax objective }\end{array}$ \\
\hline
\end{tabular}




\section{Malus/Clawback}

\begin{tabular}{|c|l|l|l|}
\hline Year & UNICREDIT & \multicolumn{1}{|c|}{ INTESA } & MONTE DEI PASCHI DI SIENA \\
\hline $\mathbf{2 0 1 3}$ & $\begin{array}{l}\text { CLAWBACK: applicable to performance linked incentives } \\
\text { paid on assumptions later revealed to be erroneous; } \\
\text { MALUS: in function of verification from time to time of the } \\
\text { entry gates }\end{array}$ & $\begin{array}{l}\text { The company reserves the right to activate mechanisms of } \\
\text { clawback, meaning return of prizes already paid, as required } \\
\text { by the rules, in the case of disciplinary initiatives and provi- } \\
\text { sions envisaged in response to fraudulent conduct or gross } \\
\text { negligence by personnel, further taking into account profiles } \\
\text { of a legal, national insurance and tax nature on the subject; } \\
\text { MALUS: function of verification from time to time of the } \\
\text { entry gates }\end{array}$ & PRESENT (but specifications not found) \\
\hline $\mathbf{2 0 1 5}$ & $\begin{array}{l}\text { CLAWBACK: on shares and in general in variable remuner- } \\
\text { ations; } \\
\text { MALUS: in function of verification from time to time of the } \\
\text { entry gates }\end{array}$ & $\begin{array}{l}\text { The company reserves the right to activate mechanisms of } \\
\text { clawback, meaning return of prizes already paid, as required } \\
\text { by the rules, in the case of disciplinary initiatives and provi- } \\
\text { sions envisaged in response to fraudulent conduct or gross } \\
\text { negligence by personnel, further taking into account profiles } \\
\text { of a legal, national insurance and tax nature on the subject; } \\
\text { MALUS: function of verification from time to time of the } \\
\text { entry gates }\end{array}$ & $\begin{array}{l}\text { Reinforcement of assessments on the subject of adjustment } \\
\text { introduction of indicators of a qualitative nature linked to the } \\
\text { conduct of personnel in the course of their work relationship; } \\
\text { deferred component subjected to the mechanisms of malus; } \\
\text { mix of indicators that weigh in the deferred component (e.g. } \\
\text { Tier 1, liquidity, etc.) }\end{array}$ \\
\hline
\end{tabular}

\section{Deferral period}

\begin{tabular}{|c|c|c|c|c|c|c|}
\hline \multirow{2}{*}{ Year } & \multicolumn{2}{|c|}{ UNICREDIT } & \multicolumn{2}{|c|}{ INTESA } & \multicolumn{2}{|c|}{ MONTE DEI PASCHI DI SIENA } \\
\hline & Relevant Personnel & Others & Relevant Personnel & Others & Relevant Personnel & Others \\
\hline 2013 & 5 years & 3 years & 3 years & $\begin{array}{l}\text { For the "Extended Perime- } \\
\text { ter" a simpler method envis- } \\
\text { aged for deferral (lump sum } \\
\text { after two years) }\end{array}$ & 3 years & 3 years \\
\hline 2015 & 5 years & 3 years & 5 years & 3 years & 5 years & 3 years \\
\hline
\end{tabular}




\section{Golden parachute and severance indemnity}

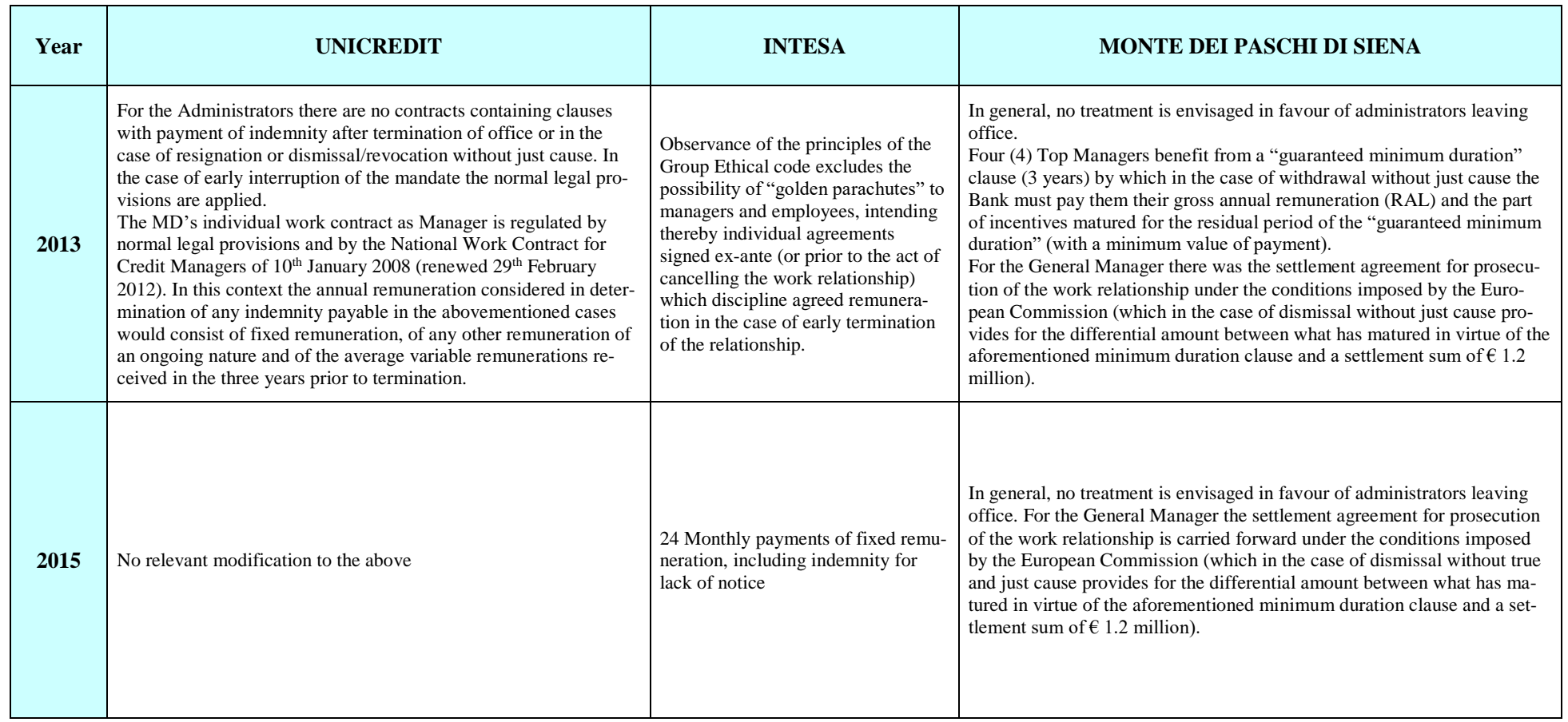

